\title{
Evaluation of the Properties of Lightweight Concrete Using Periwinkle Shells as a Partial Replacement for Coarse Aggregate
}

\section{*11OLUGBENGA JOSEPH OYEDEPO}

Department of Civil and Environmental Engineering, Federal University of Technology Akure, Nigeria *Correspondence author Email:oyedepoo@yahoo.co.uk; Tel No.+234-803-354-7639

\begin{abstract}
The properties of lightweight concrete, such as aggregate impact value, aggregate crushing value and compressive strength were assessed utilizing periwinkle shell (PWS) as partial replacement for coarse aggregate. Standard mix of 1:2:4 with varying percentages of $0 \%, 10 \%, 20 \%, 30 \%, 40 \%, 50 \%$ and $100 \%$ partial replacement of PWS using water/cement (W/C) ratio of 0.55 was used. Seventy two cubes of $150 \mathrm{~mm} \times 150 \mathrm{~mm} \times 150$ $\mathrm{mm}$ were casted; allowed to set for 24 hours before remolding, and were properly cured. The strength characteristics of each cube were evaluated using Compressive Testing machine at the curing ages of 7, 14, 21 and 28 days. The ACV and AIV obtained are $31.59 \%$ and $22.61 \%$ respectively which is within the acceptable limit. An optimum compressive strength value of $16.79 \mathrm{~N} / \mathrm{mm}^{2}$ and $16.71 \mathrm{~N} / \mathrm{mm}^{2}$ was obtained with the addition $20 \%$ and $30 \%$ partial replacement of coarse aggregate with PWS in 28 days. These values are within 15-25 $\mathrm{N} / \mathrm{mm}^{2}$ and it is suitable for Lightweight concrete. The research demonstrates that the utilization of PWS in structural/insulating lightweight concrete, at lower volume of replacement, will reduce the utilization of granite in concrete. Thus, decreasing the production cost of concrete and the ecological contamination brought about by the dumping of periwinkle shell. () JASEM

http://dx.doi.org/10.4314/jasem.v20i3.2
\end{abstract}

Keywords: Lightweight Concrete, Periwinkle, Aggregate Impact Value, Aggregate Crushing Value, Compressive Strength, Environmental Pollution.

Concrete is widely used as construction material for various types of structures due to its durability. Concrete structures are built in highly polluted urban and industrial areas, aggressive marine environments and many other hostile conditions where other materials of construction are found to be non-durable; this make the use of concrete unavoidable.

In concrete, coarse aggregate takes around $60 \%$ of the general self-weight of normal weight concrete (NWC), in this manner determine the amount of reinforcement required to resist forces acting on the structural member. Be that as it may, increasing cost of construction and the need to decrease environmental stresses to make construction reasonable, has required exploration into the utilization of alternative materials or locally accessible materials. The utilization of locally accessible materials to partially or fully replace the costly conventional materials, to produce light-weight concrete structures (LWC) will reduced the construction cost, drive infrastructural development and make engineering construction sustainable. Hence, the study will investigate the properties of concrete utilizing periwinkle shells as partial replacement for coarse aggregate.

\section{Literature Review}

Concrete, the most utilized number one structural material is a composite mixture of cement, aggregate, water and admixture. Increase in the cost of construction through the use of conventional materials as aggregate has led to a quest for alternative materials for the production of lightweight concrete. Structural lightweight concrete can be defined as a type of concrete which includes an expanding agent in that it increases the volume of the mixture while giving additional qualities such as nailbility and lessened the dead weight. The main specialties of lightweight concrete are its low density and thermal conductivity. Structural lightweight concrete provides a more efficient strength-to-weight ratio in structural elements. However, sufficient water cement ratio is vital to produce adequate cohesion between cement and water. Insufficient water can cause lack of cohesion between particles, thus loss in strength of concrete. Likewise too much water can cause cement to run off aggregate to form laitance layers, subsequently weakens in strength. Structural lightweight concrete has density of $1440 \mathrm{~kg} / \mathrm{m}^{3}$ to $1840 \mathrm{~kg} / \mathrm{m}^{3}$ compared to normal weight concrete with a density in the range of $2240 \mathrm{~kg} / \mathrm{m}^{3}$ to $2400 \mathrm{~kg} / \mathrm{m}^{3}$. For structural application, the concrete strength should be greater than 17.0 MPa. Table 1.0 show the Classification of Lightweight Concrete. 
Table 1: Light weight Aggregate Concrete Classified According to Use and Physical Properties

\begin{tabular}{|c|c|c|c|c|}
\hline $\begin{array}{l}\text { Class of Lightweight } \\
\text { Aggregate Concrete }\end{array}$ & $\begin{array}{l}\text { Type of Lightweight } \\
\text { Aggregate used in concrete }\end{array}$ & $\begin{array}{l}\text { Typical Range of } \\
\text { Lightweight Concrete } \\
\text { Density }(\mathrm{kg} / \mathrm{m} 3)\end{array}$ & $\begin{array}{l}\text { Typical Range of Compressive } \\
\text { Strength MPa }\end{array}$ & $\begin{array}{l}\text { Typical Range of } \\
\text { Thermal Conductivity } \\
\mathrm{W} / \mathrm{m}^{\circ} \mathrm{K}\end{array}$ \\
\hline Structural & Structural-grade LWA C 330 & $\begin{array}{l}1440 \text { to } 1840 \text { at } \\
\text { equilibrium }\end{array}$ & $>17$ & Not specified in C 330 \\
\hline Structural/Insulating & $\begin{array}{l}\text { Either structural C } 330 \text { or } \\
\text { insulating }\end{array}$ & $\begin{array}{l}720 \text { to } 1440 \text { at } \\
\text { equilibrium }\end{array}$ & 3.4 to 17 & $\begin{array}{l}\text { C } 332 \text { from } 1.05 \text { to } 0.43 \\
\text { oven dry }\end{array}$ \\
\hline Insulating & Insulating-grade LWA C 332 & 240 to 800 over dry & 0.7 to 3.4 & $\begin{array}{l}\text { C } 332 \text { from } 0.065 \text { to } \\
0.22 \text { oven dry }\end{array}$ \\
\hline
\end{tabular}

Source: ASTM C 330 and C 332-09 (2007)

Several researches have been carried out on the utilization of alternatives material as aggregate in concrete production; Ramezanianpour et al (2009) and Ndoke (2006) assessed the performance of palm kernel shells as a partial replacement for coarse aggregate in asphalt concrete, while Falade (1992) explored the appropriateness of palm kernel shells as aggregates in light and dense concrete for structural and non-structural purposes. Nimityongskul and Daladar (1995) examined the utilization of coconut husk ash, corn cob ash and peanut shell ash as cement replacement in concrete production. Slim and Wakefield (1991)explored the utilization of water works sludge in the manufacture of clay bricks. Olutoge (2010) examined the suitability of sawdust and palm kernel shells as replacement for fine and coarse aggregate in the production of reinforced concrete slabs. Olanipekun (2006) in his own research, compared concrete made with coconut shells and palm kernel shells as replacement for coarse aggregates and concluded that coconut shells performed better than palm kernel shells as replacement for conventional aggregates in the of concrete.

Osayemwen (1992) examined the utilization of periwinkle shells as alternative material to granite chips as coarse aggregate in concrete and concluded that the use of periwinkle shells for concrete would result in low cost housing delivery especially in the riverine areas where they are found as waste. Emiero and Oyedepo (2012) worked on the Investigation on the strength and workability of concrete using palm kernel shell and palm kernel fiber as a coarse aggregate, the values of the slump obtained for mix 1:11/2:3 and Mix 1:2:4 for concrete produced with palm kernel shell (PKS) and palm kernel fiber (PKF) are $30 \mathrm{~mm}$ and $38 \mathrm{~mm}$ which indicate true slump. The concrete mix ratio PKS: PKF of 50:50 for $1: 1 \frac{1 / 2: 3}{}$ and 1:2:4 has compressive strength of $12.29 \mathrm{~N} / \mathrm{mm}^{2}$ and $10.38 \mathrm{~N} / \mathrm{mm}^{2}$ after 28 days, which confirms light weight concrete. Oyedepo et al (2014) additionally examined the properties of concrete using sawdust as partial replacement for sand; they confirm that the utilization of sawdust as partial replacement of sand between 0 to $25 \%$ will adds to decrease in sawdust waste produced without adversely affecting concrete strength.

In another research on performance of coconut shell ash (CSA) and palm kernel shell (PKSA) ash as partial replacement for cement in concrete by Oyedepo et al (2015); the research demonstrate that the utilization of CSA and PKSA as a partial replacement for cement in concrete, at lower volume of replacement, will enhance the reduction of cement usage in concretes, accordingly decreasing the production cost and the ecological contamination brought on by the dumping of the agricultural waste. Osarenmwinda and Awaro (2009) researched the potential of periwinkle shell as coarse aggregate for concrete. The results showed that concretes produced with $1: 1: 2, \quad 1: 2: 3$ and $1: 2: 4$ mixes indicated compressive strengths of $25.67 \mathrm{~N} / \mathrm{mm}^{2}, 19.50 \mathrm{~N} / \mathrm{mm}^{2}$ and $19.83 \mathrm{~N} / \mathrm{mm}^{2}$ at 28 days curing age respectively. These strength values met the ASTM-77 recommended minimum strength of $17 \mathrm{~N} / \mathrm{mm}^{2}$ for structural light weight concrete while the mixes with compressive strengths of $14.00 \mathrm{~N} / \mathrm{mm}^{2}$ and 16.50 $\mathrm{N} / \mathrm{mm}^{2}$ respectively did not meet the standard values.

Periwinkle (Tympanotonusfuscatu sand

Pachymelaniaaurita) is a common name for a group of molluscan shellfish with either smooth or rough spiral shells (Ideriah, et al., (2006). There are hundred species each of two genera of Nigerian Periwinklesradula (a brackish water habitat) and Pachymelaniaaurita(a fresh water species) (Bukola $e t$ al., 2006; Uwadiae, et al. 2009). A survey by Umoh and Olusola (2012) discovered that large quantities of periwinkle shells are available in many riverine communities of the South-South geopolitical region of Nigeria. Most periwinkles are edible, the fleshy (edible) parts are usually removed after boiling in water, and the shells are usually discarded

In Nigeria, periwinkle shell had been used both for construction and non-construction purposes. Badmus, et al., (2007) used the physiochemical properties of periwinkle shell ash burnt in a furnace at $300^{\circ} \mathrm{C}$ for 2 hours and sifted with $180 \mu \mathrm{m}$ sieve in the removal of lead ion and copper from industrial waste waters.

\section{OLUGBENGA JOSEPH OYEDEPO}


Dahuasi (2002), Olorunoje and Olalusi (2003), Adewuyi and Adegoke (2008), Agbede and Manasseh (2009), and Falade, et al., (2010) made utilization of the periwinkle shells (TympanotonusFuscatus) as an alternative to coarse aggregates in lightweight concrete; however, the compressive strength values obtained varied between12.12 $\mathrm{Nmm}^{-2}$ and $25.67 \mathrm{Nmm}^{-2}$ at 28 days which depends on mix proportion, type of coarse aggregate replaced by periwinkle shell and water cement ratio.

This paper accordingly assesses the properties of lightweight concrete using varying percentages of periwinkle shells as a partial replacement for coarse aggregate. The compressive strengths of cubes obtained are evaluated to determine the optimum percentage replacement.

\section{MATERIALS AND METHODS}

Material Used: The materials used during the study are ordinary Portland cement, granite shipping of 20 $\mathrm{mm}$ nominal size from Johnson and Johnson quarry in Akure, fine aggregate (river sand) and periwinkle shell (Pachymelaniaaurita) obtained from Calabar in Cross Rivers State Nigeria.

Methods: The following tests were conducted on the materials in accordance with BS 1375: 1997, BS 812112-1990 and IS: 2386 (Part IV) - 1963.

i. Grain Size Analysis

ii. Aggregates Impact Value Test (AIV) on Periwinkle,

iii. Aggregate Crushing value (ACV) test on Periwinkle,

iv. Slump Test,

Grain Size Analysis: Grain sieve analysis helps to determine the particle size distribution of the coarse and fine aggregates. This is done by sieving the aggregates as per IS: 2386 (Part I) - 1963. The test sample is dried to a constant weight at a temperature of $110+5^{\circ} \mathrm{C}$ and weighed. The sample is sieved by using a set of IS Sieves- $80 \mathrm{~mm}, 63 \mathrm{~mm}, 50 \mathrm{~mm}, 40$ $\mathrm{mm}, 31.5 \mathrm{~mm}, 25 \mathrm{~mm}, 20 \mathrm{~mm}, 16 \mathrm{~mm}, 12.5 \mathrm{~mm}, 10$ $\mathrm{mm}, 6.3 \mathrm{~mm}, 4.75 \mathrm{~mm}, 3.35 \mathrm{~mm}, 2.36 \mathrm{~mm}, 1.18 \mathrm{~mm}$, $600 \mu \mathrm{m}, 300 \mu \mathrm{m}, 150 \mu \mathrm{m}$ and $75 \mu \mathrm{m}$. On completion of sieving, the material on each sieve is weighed, while the cumulative weight passing through each sieve is calculated as a percentage of the total sample weight. The results of the sieve analysis were recorded graphically on a semi-log graph with particle size as abscissa (log scale) and the percentage smaller than the specified diameter as ordinate.

Aggregate Impact Value Test: This test is done to determine the aggregate impact value of coarse aggregates using Impact testing machine conforming to IS: 2386 (Part IV) - 1963. The test sample passing through $12.5 \mathrm{~mm}$ IS Sieve - $100 \%$ and retained on $10 \mathrm{~mm}$ IS Sieve $-100 \%$. The sample was oven-dried for $4 \mathrm{hrs}$ at a temperature of 100 to $110^{\circ} \mathrm{C}$ and cooled; the cup of the impact testing machine was fixed firmly in position on the base of the machine; and the whole of the test sample placed in it and compacted by 25 strokes of the tamping rod. However, the hammer was raised to $380 \mathrm{~mm}$ above the upper surface of the aggregates in the cup and allowed to fall freely onto the aggregates. The test sample was subjected to a total of 15 such blows, each being delivered at an interval of not less than one second. Two such tests were carried out and the mean of the results reported, the aggregate impact value was calculated as follows:

Aggregate impact value $=(\mathrm{B} / \mathrm{A}) \times 100 \%$

Aggregate Crushing Value Test: This test helps to determine the aggregate crushing value of coarse aggregates as per IS: 2386 (Part IV) - 1963. The apparatus used is cylindrical measure and plunger, Compression testing machine, IS Sieves of sizes $12.5 \mathrm{~mm}, 10 \mathrm{~mm}$ and $2.36 \mathrm{~mm}$. The aggregates passing through $12.5 \mathrm{~mm}$ and retained on $10 \mathrm{~mm}$ IS Sieve are oven-dried at a temperature of 100 to $110^{\circ} \mathrm{C}$ for 3 to 4hrs. ii) The cylinder of the apparatus is filled in 3 layers, each layer tamped with 25 strokes of a tamping rod. The weight of aggregates is measured (Weight ' $A$ '). The surface of the aggregates is then leveled and the plunger inserted. The apparatus is then placed in the compression testing machine and loaded at a uniform rate so as to achieve $40 \mathrm{t}$ load in 10 minutes. After this, the load is released. The sample is then sieved through a $2.36 \mathrm{~mm}$ IS Sieve and the fraction passing through the sieve is weighed (Weight ' $\mathrm{B}$ '). Two such tests were carried out and the mean of the results reported, the aggregate crushing value was calculated as follows:

Aggregate crushing value $=(\mathrm{B} / \mathrm{A}) \times 100 \%$.

Research Approach: The periwinkle shells were washed to remove dirt and sun-dried for many days at ambient temperature while, a standard mix ratio 1:2:4 by weight of cement: sand: granite + PWKS with varying percentages of $0 \%, 10 \%, 20 \%, 30 \%, 40 \%$, $50 \%$ and $100 \%$ partially replacement of periwinkle shell was used. The water/cement (W/C) ratio used was 0.55 for all proportion of the mixes. Seventy two cubes of $150 \mathrm{~mm} \times 150 \mathrm{~mm} \times 150 \mathrm{~mm}$ with three cubes were made for each mix in accordance with BS 1881 (1970); the workability of the fresh concrete was determined using a slump test while the specimens were allowed to set for 24 hours before remolding, and were properly cured. The strength characteristics of each cube were carried out using a loading rate of $120 \mathrm{kN} / \mathrm{min}$ on a $600 \mathrm{kN}$ Compressive Testing machine shown in Plate 1.0 at the curing ages of 7, 14, 21 and 28 days 


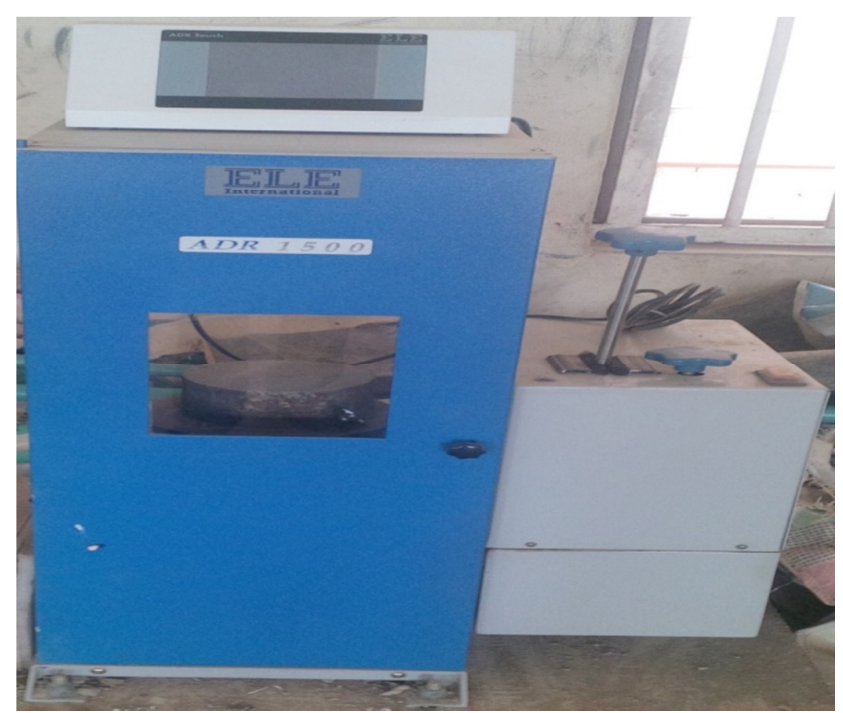

Plate 1.0: ELE Compressive Testing machine

\section{RESULTS AND CONCLUSION}

Figure 1 is the particle size distribution curve for the fine aggregate, Tables 2 to 4 shows the results of various test carried out to determine the physical properties of periwinkle shell. Nonetheless, Figure 2 is strength variation of partial replacement of cement with periwinkle shell 


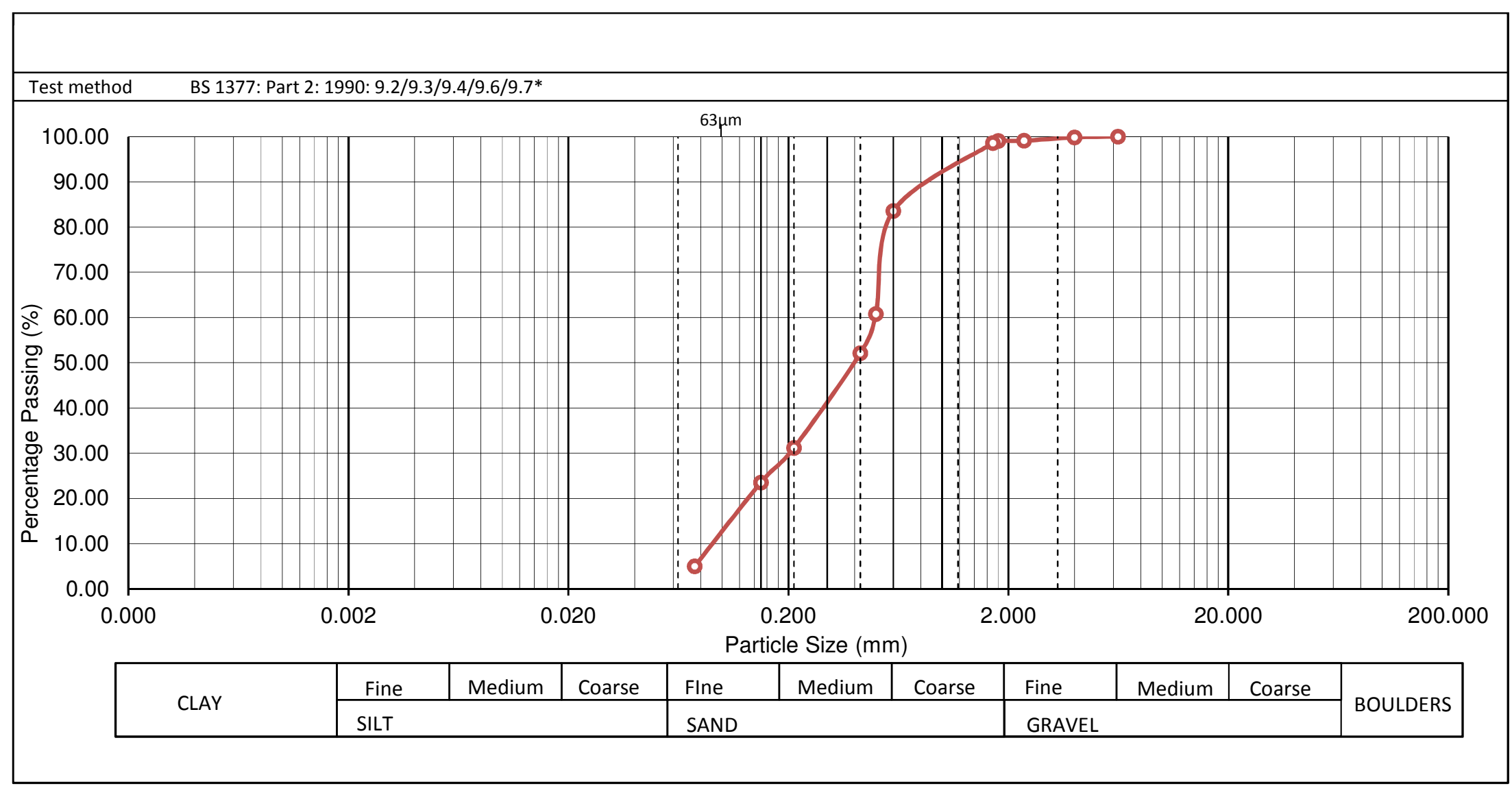

Fig1: Particle Size Distribution Analysis of Fine Aggregate 
From the curve obtained

$$
\begin{gathered}
C_{u}=\frac{D_{60}}{D_{10}}=\frac{0.48}{0.08}=6.0 \\
C_{c}=\frac{\left(D_{30}\right)^{2}}{D_{10} D_{60}}=\frac{0.2^{2}}{0.08 \times 0.48}=1.04
\end{gathered}
$$

Where: $\mathrm{D}_{60}$ is the particle diameter, at which 60 percent by weight of the soil is finer,

$\mathrm{D}_{30}$ is particle diameter, at which 30 percent by weight of the soil is finer,

$\mathrm{D}_{10}$ is particle diameter, at which 10 percent by weight of the soil is finer,

$\mathrm{C}_{\mathrm{u}}$ is the coefficient of uniformity and $\mathrm{C}_{\mathrm{c}}$ is the coefficient of curvature

Note: A well graded soil has a $C_{u}$ value of 5 or more; thus, the fine soil is well graded since the $C_{u}$ is 6 i.e more than 5

\begin{tabular}{|c|c|c|c|c|c|c|c|}
\hline $\begin{array}{c}\% \\
\text { Test }\end{array}$ & $\begin{array}{c}\text { Slump } \\
(\mathrm{mm})\end{array}$ & $\begin{array}{c}\text { Weight }(\mathrm{kg}) \text { of } \\
\text { Fully Compacted }\end{array}$ & $\begin{array}{c}\text { Weight }(\mathrm{kg}) \text { of } \\
\text { Partially } \\
\text { Compacted } \\
\end{array}$ & $\begin{array}{l}\text { Compacted } \\
\text { Factor }\end{array}$ & $\begin{array}{c}\text { Air } \\
\text { Entrainment \% }\end{array}$ & $\begin{array}{c}\text { Pressure } \\
\text { of Air in } \\
\text { Bar }\end{array}$ & $\begin{array}{l}\text { W/C } \\
\text { Ratio }\end{array}$ \\
\hline 0 & 65 & 16.6 & 16.0 & 0.96 & 1.5 & 1.5 & .57 \\
\hline 10 & 60 & 16.2 & 15.2 & 0.94 & 2.0 & $1 . .5$ & .60 \\
\hline 20 & 50 & 16.0 & 14.2 & .89 & 1.5 & 1.5 & .60 \\
\hline 30 & 45 & 15.7 & 13.9 & .89 & 2.0 & 1.5 & .62 \\
\hline 40 & 45 & 14.5 & 13.0 & .90 & 2.5 & 1.5 & .62 \\
\hline 50 & 50 & 15 & 13.2 & .88 & 1.0 & 1.5 & .65 \\
\hline 100 & 50 & 11.3 & 11.1 & .98 & 2.5 & 1.5 & 0.60 \\
\hline
\end{tabular}

Table 2: Results of the Test Carried out on The Concrete Mix

Table 3: Aggregate Crushing Value of Periwinkle Shell

\begin{tabular}{lccc}
\hline & A & B & C \\
\hline Wt. of Sample $(\mathrm{g})$ & 181 & 193 & 198 \\
Wt. Passing Separator $(\mathrm{g})$ & 17 & 20 & 19 \\
ACV $(\%)$ & 9.39 & 10.36 & 9.60 \\
Average ACV value & & 9.78 & \\
\hline
\end{tabular}

Table 4: Aggregate Impact Value of Periwinkle Shell

\begin{tabular}{lccc}
\hline & A & B & C \\
\hline Wt. of Sample (g) & 211 & 206 & 210 \\
Wt. Passing Separator $(\mathrm{g})$ & 58 & 57 & 62 \\
AIV (\%) & 27.49 & 27.67 & 29.52 \\
Average AIV value & & 28.23 & \\
\hline
\end{tabular}

The slump value ranges between $35 \mathrm{~mm}$ to $55 \mathrm{~mm}$ which represents true slump, the aggregate crushing value (ACV) and aggregate impact value (AIV) obtained are $31.59 \%$ and $22.61 \%$ respectively which is within the acceptable limit of +3 to -3 in accordance with BS1375

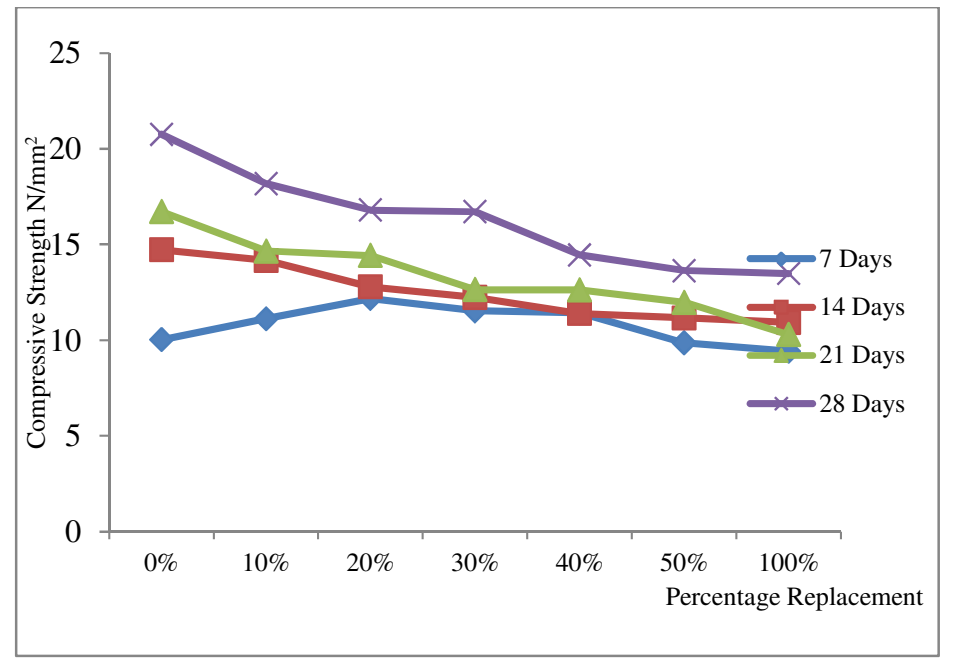

Fig 2: Strength Variation of Partial Replacement of Cement with Periwinkle Shell 
The study gives an optimum compressive strength value of $16.79 \mathrm{~N} / \mathrm{mm}^{2}$ and $16.71 \mathrm{~N} / \mathrm{mm}^{2}$ respectively with the addition $20 \%$ and $30 \%$ partial replacement of coarse aggregate with periwinkle shell in 28 days. The value of the compressive strength obtained which falls within $15-25 \mathrm{~N} / \mathrm{mm}^{2}$ as specify in Rigid Pavement Design Manual 2009 is suitable for Lightweight concrete such as Foot Bridge, lintel, wearing course of light weight road and other light structures. The utilization of PWS as a partial replacement for coarse aggregate will produced a cheaper structural lightweight concrete using the optimum compressive strength value specify in the research.

Conclusion: In this study, the slump value ranges between $35 \mathrm{~mm}$ to $55 \mathrm{~mm}$ which represents true slump; while the ACV and AIV of $31.59 \%$ and $22.61 \%$ obtained are satisfactory.An optimum compressive strength value of $16.79 \mathrm{~N} / \mathrm{mm}^{2}$ and $16.71 \mathrm{~N} / \mathrm{mm}^{2}$ obtained respectively with the addition $20 \%$ and $30 \%$ partial replacement of coarse aggregate with PWS in 28 days is suitable for Lightweight concrete structures. The research demonstrates that the use of PWS in concrete, at lower volume of replacement, will enhance the reduction of natural aggregate usage, which will reduce the cost of production.

\section{References}

Adewuyi, A. P; Adegoke, T. (2008). Exploratory Study f Periwinkle Shells As Coarse Aggregate In Concrete Works. Journal of Applied Sciences Research, 4(12): 1678-1681.

Agbede, O. I; and Manasseh, J, (2009).Suitability of Periwinkle Shell as Partial Replacement for River Gravel in Concrete.Leonardo Electronic Journal of Practices and Technologies.Issue 15:59-66.

ASTM C-331/C331M (2007).Standard Specification for Lightweight Aggregates for Concrete Masonry Units

ASTM C 330 (2007): Standard Specification for Lightweight Aggregates for Structural Concrete

ASTM C 330-09 (2007): Standard Specification for Lightweight Aggregates for Insulating Concrete

Badmus, M. A. O.;Audu, T. O. K.; and Anyata, B.U. (2007). Removal of Lead ion from Industrial Wastewaters by Activated Carbon Prepared from Periwinkle Shells (typanotonusfuscatus); Turkish Journal of Engineering and Environmental Sciences, 31( 4): 251-263
Bukola, C; Adebayo-tayo, A; Onilude, A.A; Ogunjobi A; and Damilola, O. A.

(2006).Bacteriological and Proximate Analysis of Periwinkles from Two Different Creeks in Nigeria. World Applied Sciences Journal.1 (2): 87-91.

BS1375 (1997).Structural use of concrete - Part 1: Code of practice for design and construction. London: British Standards Institution

BS 812-112-1990.Testing Aggregates. Part 112: Methods for Determination Of Aggregate Impact Value (AIV)

Dahunsi, B.I.O; and Bamisaye, J.A (2002).Use of Periwinkle Shells Ash as a Partial Replacement for Cement in Concrete. Paper presented at the annual conference of the Material Society of Nigeria, Akure, Nigeria

Emiero, C; and Oyedepo, O.J (2012) An Investigation on The Strength and Workability of Concrete Using Palm Kernel Shell and Palm Kernel Fiber As A Coarse Aggregate; International Journal of Scientific \& Engineering Research3 (4): 1-5

Falade, F. (1992); The Use of Palm Kernel Shell as Coarse Aggregate in Concrete, Journal of Housing Science, 16 (3): 213-219.

Falade, F.; Ikponmwosa, E. E.; and Ojediran, N. I., (2010).Behaviour of Lightweight Concrete Containing Periwinkle Shells at Elevated Temperature.Journal of Engineering Science and Technology. 5 (4): $379-390$.

Ideriah, T. K.; Braide, S. A.; and Briggs, A. O. (2006).Distribution of Lead and total Hydrocarbon in Tissues of Periwinkles (Tympanotonus fuscatus and Pachymelaniaaurita) in the upper Bonny River, Nigeria. Journal of Applied Sciences and Environmental Management. 10 (2): 145 - 150.

IS: 2386 (Part IV) - (1963): Methods of Tests for Aggregate for Concrete

Ndoke, P.N.(2006). Performance of Palm Kernel Shells as a Partial Replacement for Coarse Aggregate in Asphalt Concrete, Leonardo Electronic Journal of Practices and Technologies, 5 (9): 145-152.

Nimityongskul, P. and Daladar, T.U. (1995). Use of Coconut Husk Ash, and Peanut Ash as Cement Replacement, Journal of Ferrocement, 25 (1): 35-44. 
Olorunoje, G. S; and Olalusi, O. C. (2003).Periwinkle Shell, as Alternative to Coarse Aggregate in Light Weight Concrete; International Journal of Enviromnental Issues.1(1).131 - 133.

Olanipekun, E.A. (2006).A Comparative study of concrete properties using coconut shell and palm kernel shell as coarse aggregates.Journal of Building and Environment. 41 (3):Pp 297-301.

Olutoge, F. A. (2010). Investigations of Sawdust and Palm Kernel Shells as Aggregate Replacement. ARPN Journal of Engineering and Applied Sciences, 5 (4): 1819-6608.

Osayemwen, E.O. (1992): An investigation of the characteristics of lightweight concrete made of periwinkle shells, palm kernel shells, sand and sawdust as aggregates. Unpublished M.Sc. Dissertation.Department of Civil Engineering, University of Lagos Nigeria.

Oyedepo, O.J; Oluwajana, S.D; and Akande, S.P (2014).Investigation of Properties of Concrete Using Sawdust as Partial Replacement for Sand; Journal of Civil and Environmental Research.International Institute for Science, Technology and Education Hong Kong.6 (2): 3542.

Oyedepo, O.J; Olanitori, L.M; and Akande, P. S. (2015).Performance of Coconut Shell Ash and Palm Kernel Shell Ash as Partial Replacement for Cement in Concrete; Journal of Building Materials and Structures Algeria.2 (1): 18-24.
Osarenmwinda, J. O; and Awaro, A. O. (2009). The potential use of periwinkle shell as Coarse Aggregate for Concrete. Advanced Materials Research, 62: Pp64:39-43.

Ramezanianpour, A.A; Mahdikhani, M; and Ahmadibeni, G (2009). The Effect of Rice Husk Ash on Mechanical Properties and Durability of Sustainable Concretes, International Journal of Civil Engineering, 7 (2): 83-91.

Rigid Pavement Design Manual(2009).Published byFlorida Department of Transportation USA, Pavement Management Office.Pp. 2.6.0

RIEM (1975).Terminology and definitions of lightweight concrete, Recommendation LCI, $1{ }^{\text {st }}$ Edition

Slim, J.A; and Wakefield, R. W (1991).The utilisation of Sewage Sludge in the Manufacture of Clay Bricks.Water S. A., 17(3): 197-202.

Umoh, A. A. and Olusola, K. O (2012). Effect of Different Sulphate Types and Concentrations on Compressive Strength of Periwinkle Shell Ash Blended Cement, International Journal of Engineering \& Technology. 12 (5): 10-17.

Uwadiae, R. E; Edokpayi, C.A; and Egonmwan, R. I. (2009). The Ecology and Natural Food Components of PachymelaniaauritaMÜLLER (Gastropoda: Melaniidae) in a Coastal Lagoon. Report and Opinion.1(5). 